\title{
DISTRIBUTION AND EPIDEMIC PATTERN OF CERCOSPORA LEAF SPOT DISEASE OF SUGAR BEET IN EGYPT. \\ Khalil,F.A. $^{*}$;M.M.M.Saber ${ }^{*}$;E.M.M.El-Assuty ${ }^{* *}$ and M. A. Yassin ${ }^{* *}$ \\ * Plant Pathology Dept., Agriculture College, Cairo Univ. \\ ** Plant Pathology Research Institute, ARC
}

\begin{abstract}
Cercospora leaf spot disease "CLS" was detected in the most of beet growing areas in Egypt with percentage of disease severity ranged from $5-75 \%$. No symptoms were observed in Minya, Bani-Suef or fayoum governorates. Epidemiological analysis of CLS during the period 2002-2005, revealed that disease progress rate "DPR" and area under disease progress curve "AUDPC" values were ranged from (0.08 - 0.58; 0.10-0.54 and $0.09-0.50)$ and $(3.2-24.4 \% ; 3.2-23.2 \%$ and $3.0-19.6 \%$ ) for the first, second and third years respectively. In respect of sowing dates results showed that DPR and AUDPC values were ranged from $0.45-0.58$; 0.04$0.13 \& 0.09-0.17$ and $14.9-24.4 \% ; 2.1-4.5 \% \& 3.2-5.6 \%$ for the first (August), second (September) and third (October) sowing dates respectively. It was proved that the greatest effect of Cercospora leaf spot disease "CLS" on sugar beet in Egypt was in the $1^{\text {st }}$ sowing date. Increase of disease rates and effects in the $1^{\text {st }}$ sowing date may due to presence of favorable environmental conditions.

Key words: Cercospora leaf spot, Distribution, Epidemic pattern.
\end{abstract}

\section{INTRODUCTION}

Sugar beet (Beta vulgaris $\mathrm{L}$ ) is one of the most important sugar crops in many countries of the world. Currently approximately $37 \%$ of world sugar is produced from sugar beet. In Egypt, about $30 \%$ of the total area of sugar crops was cultivated with sugar beet (Ministry of Agriculture, 2005).

Sugar beet plants have been reported to be attacked by many pathogenic fungi which infect different plant parts, from seedling to mature stages. Leaf spots are the most common and severe diseases. Cercospora leaf spot "CLS" caused by $C$. beticola Sacc. is one of the most widespread, destructive and economically significant disease of sugar beet in the world (Rossi, et al,1995). The pathogen not only causes reduction in root size and sucrose content but also decreases purity of the juice derived from diseased beets (Smith \& Martin, 1978). The disease regularly causes yield loss and the extent of damage depends on time of initiation, progress and severity of the epidemic. C.beticola proved to affect a sugar-content reduction of $18.2 \%$ in the susceptible variety and of $18.0 \%$ in the tolerant variety (Cion, et al, 2004).

CLS disease was found in most of sugar beet growing zones, i.e. Greece, Italy, Spain, USA (Smith, 1985) and Germany (Wolf \& Verreet, 2002). C. beticola distribution in the Mediterranean basin was also studied over 46 sugar beet growing zones. Disease intensity ranged from high values to traces. Changes in disease intensity are explained on the basis of ecological and epidemiological factors (Rossi, et al, 1995). CLS was recorded in Egypt for the first time on sugar beet by Jones, 1925. In October 1976, leaf spot 
symptoms were noticed on sugar beet leaves grown in a farm near Alexandria (El-Kazzaz, 1977). The disease was then found in Noubaria Sector, \& Kafr El-Sheikh (El-Kholi, 1995). CLS was the most frequent disease in sugar beet, in four governorates over three years. Disease severity ranged from $50 \%$ to $72 \%$ (El-Sayed, 2000).

This study was conducted to recognize the characteristics of CLS distribution and epidemic patterns in Egypt as affected by environmental conditions.

\section{MATERIALS AND METHODS}

Sugar beet fields were surveyed for determine leaf spot distribution and intensity, within 10 governorates i.e. Kafr El-Sheikh, Dakahliya, Gharbiya, Sharkiya, Damietta, Behaira, Nubaryia, Bani-suef, Minya and Fayoum, within the 3 growing seasons each year during the period 2002-2005. Spot percentage scale of Shane and Teng (1992) was used for disease assessment. Sugar beet fields, cultivated with Gloria cultivar, were monitored regularly; for disease assessment, every 10-15 days, beginning of the canopy closer to the end of growing seasons and disease severity \% was recorded subsequently.

\section{Disease progress curves:}

A progress curve relates a change in the number of pathogen or symptoms to time. The progress of CLS was exemplified by the observations of epidemic. Fitting of disease progress curves were carried out using excel computer program (Kranz, 1974). A plot of these disease values vs. time (a disease progress curve), summarize the effect of host, pathogen, and environment on epidemic development. An epidemic can be defined as an increase or change in disease intensity with time. The beginning of the epidemic progress, defined as an infection frequency of $50 \%$ beet plants in a natural sugar beet fields (Wolf \& Verreet, 1997). Statistical model of disease progress data for CLS can be represented as (Van Der Plank, 1963):-

$$
Y=f(t)
$$

Where $y$ is disease intensity, $t$ is time, $f(t)$ is some function of time.

\section{Disease progress rates (DPR):}

Disease progress models has parameters i.e.: initial disease $\left(\mathrm{y}_{0}\right)$ and rate of increase $\left(r_{*}\right)$ which is the slope of linearized y (i.e. $\left.y_{*}\right)$ versus time $(t)$. The parameter $\left(r_{*}\right)$ is determined by the susceptibility of the host, aggressiveness of the pathogen, and favorability of the environmental conditions. Disease progress rate was calculated using the following equation. (Van Der Plank, 1963).

$$
\mathrm{DPR}=\sum_{i}^{n-1}\left(\frac{y_{2}-y_{1}}{t_{2}-t_{1}}\right) / n
$$


Area under disease progress curves (AUDPC):

Area under disease progress curve "AUDPC" is the integration of disease severity (of CLS on beet leaf) over time. Graphic analysis program has been used for the integrations. AUDPC was calculated by trapezoidal integration in accordance with 10-15 day interval disease severity data over the season: the following equations were used (Wolf \& Verreet, 2002).

$$
\text { AUDPC }=\sum_{i}^{n-1}\left(\frac{y_{i}+y_{i+1}}{2}\right)\left(t_{i+1}-t_{i}\right) \quad \text { AUDPC }=\int_{n=1}^{180} \text { (Disease }
$$

Where $y_{i \text {-disease severity } \%,} t_{i \text {-interval of data records (days), n-number of }}$ assessments

\section{RESULTS AND DISCUSSION}

\section{Disease distribution:}

Survey of sugar beet fields revealed that Cercospora leaf spot disease "CLS" was distributed with variant severities in the most of sugar beet growing areas in the country. Fig.(1) show the pattern of disease distribution in Egypt as pointed in red dots in the map.

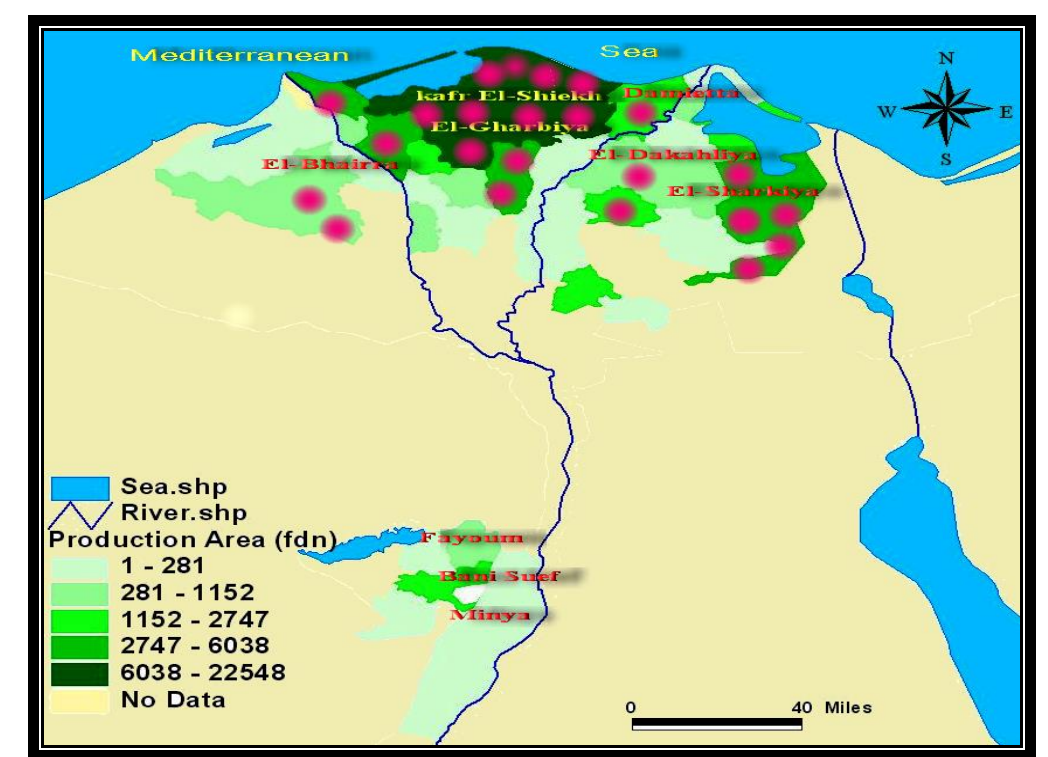

Fig (1): Distribution of Cercospora leaf spot "CLS" disease of sugar beet in EGYPT (2002-2005). 
Khalil,F.A.et al.

CLS disease was found with an intense shape in Kafr El-Sheikh (45$75 \%)$, Dakahliya (20-65\%), Gharbiya (20-60\%), Sharkiya (45-70\%), Damietta $(50-70 \%)$, and Behaira (25-60\%) governorates, but in slight intensity in Nubaryia region (4-8\%). It's rarely observed in Bani-suef, Minya and Fayoum governorats. Results were in agreement with the previous results in that, CLS was the most frequent disease in sugar beet, in Kafr El-Sheikh, Dakahliya and Behaira governorates over three years study. Disease severity ranged from $50 \%$ to $72 \%$ (El-Sayed, 2000).

It known that, $C$. beticola is the primary leaf pathogen of sugar beets, especially in regions with frequent rainfall and average daily temperatures of $20-25^{\circ} \mathrm{C}$ (Wolf \& Verreet, 2002). Warm, humid growing regions are most acutely affected by Cercospora leaf spot and constitute greater than 30\% of the area under sugar beet cultivation (Weiland \& Koch, 2004).

Changes in disease intensity previously explained on the basis of ecological and epidemiological factors by Rossi, et al (1995). They found clear correlations between summer aridity, sowing time, irrigation and disease development, but elevation above sea level appeared to reduce disease intensity. They also found that chemical control and the use of resistant cultivars had a less marked effect on disease intensity than epidemiological factors. Meteorological variables affect geographical distribution of host and pathogen and alter crop losses caused in part by changes in the efficacy of control strategies (Coakley, et al 1999).

Damages owing to this pathogen vary a great deal according to the resistance level of varieties, growing environment, the year, and the harvesting periods within each year (Rosso, 2000).

\section{Disease progress curves:}

Fig, 3, 4 \& 5 shows the disease progress curves, that fits disease severity progression over time. Progress of CLS was fitted using epidemic observations through growing seasons. Disease progress curves were sigmoid and the infection rate tends to declined towards the end of the season, possibly due to an unfavorable environmental conditions. (Pundhir \& Mukhopadhyay, 1987).

The beginning of the epidemic progress, defined as an infection frequency of $50 \%$ beet plants in natural field. Concerning the epidemic progress of the fungus, there are three successive phases. As the first stage, the horizontal distribution up to a $100 \%$ plant infection rate is considered, which in most cases needs 2-4 weeks but may be extended up to eight weeks in cases of resistant cultivars linked with unfavorable weather conditions. 
J. Agric. Sci. Mansoura Univ., 32 (5), May, 2007

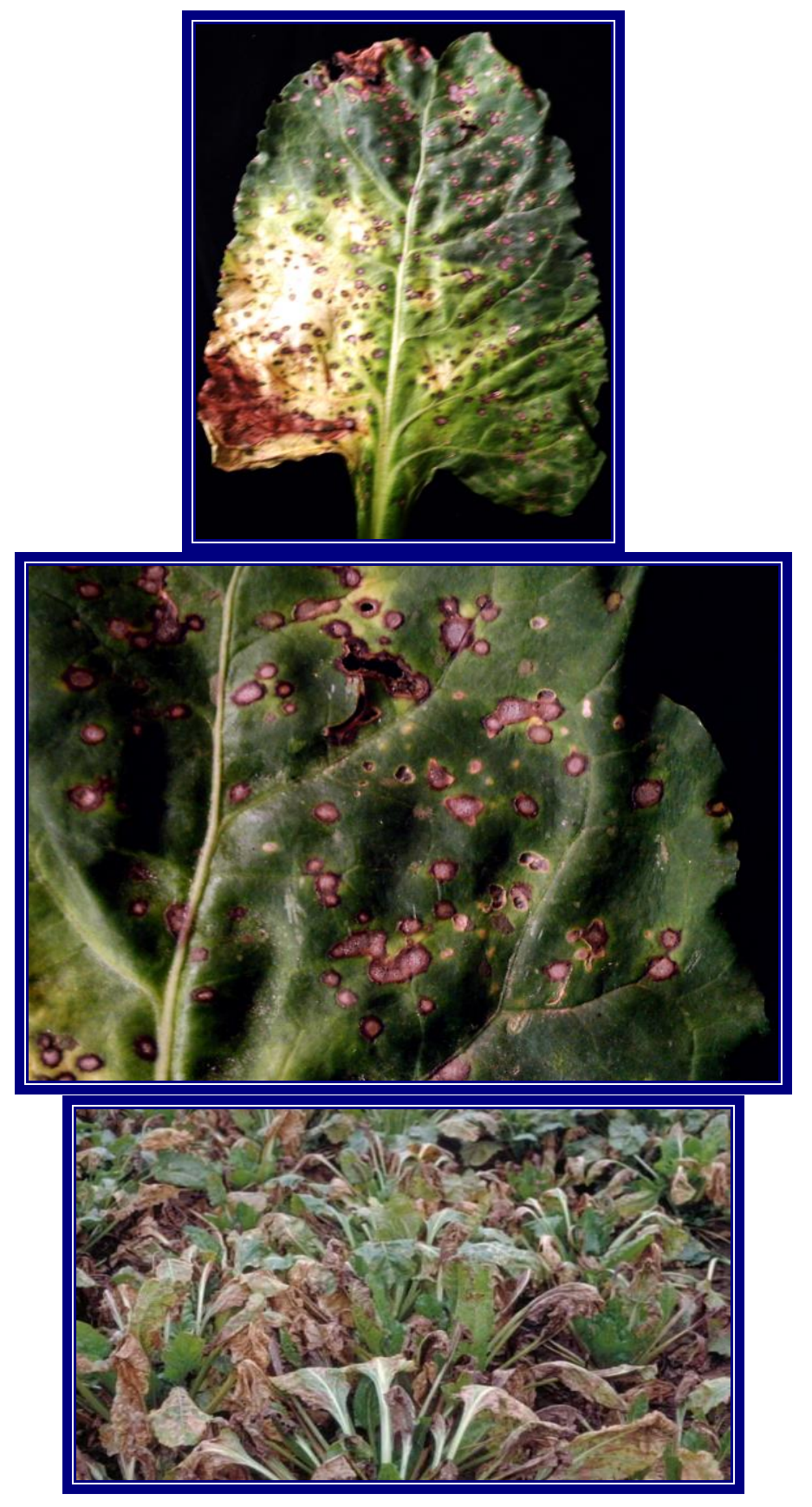

Fig (2): Symptoms \& disease severity of Cercospora leaf spot "CLS" disease of sugar beet in EGYPT. 
Khalil,F.A.et al.
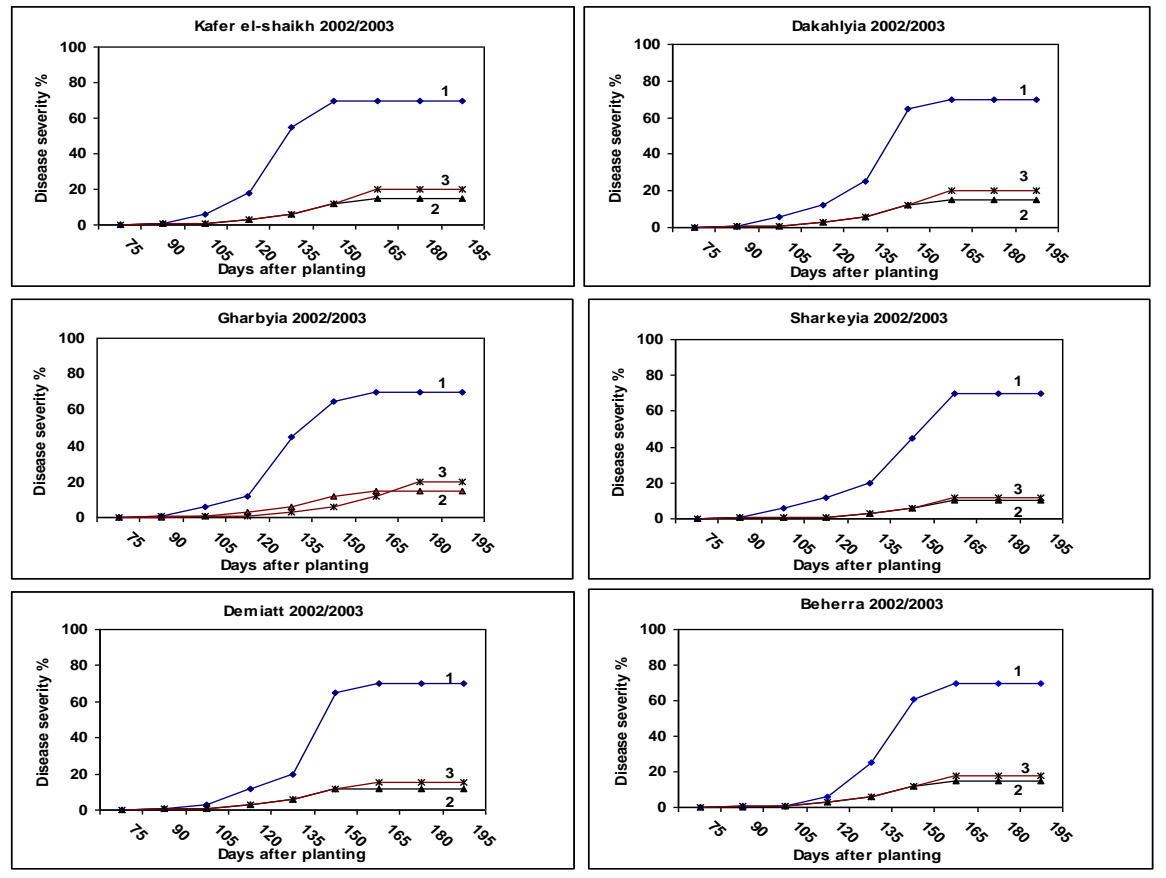

Fig (3) Disease progress curve "DPC" of Cercospora leaf spot disease of sugar beet (2002-2003). Curves No. 1, 2, 3 represents first, second \&third sowing dates respectively.
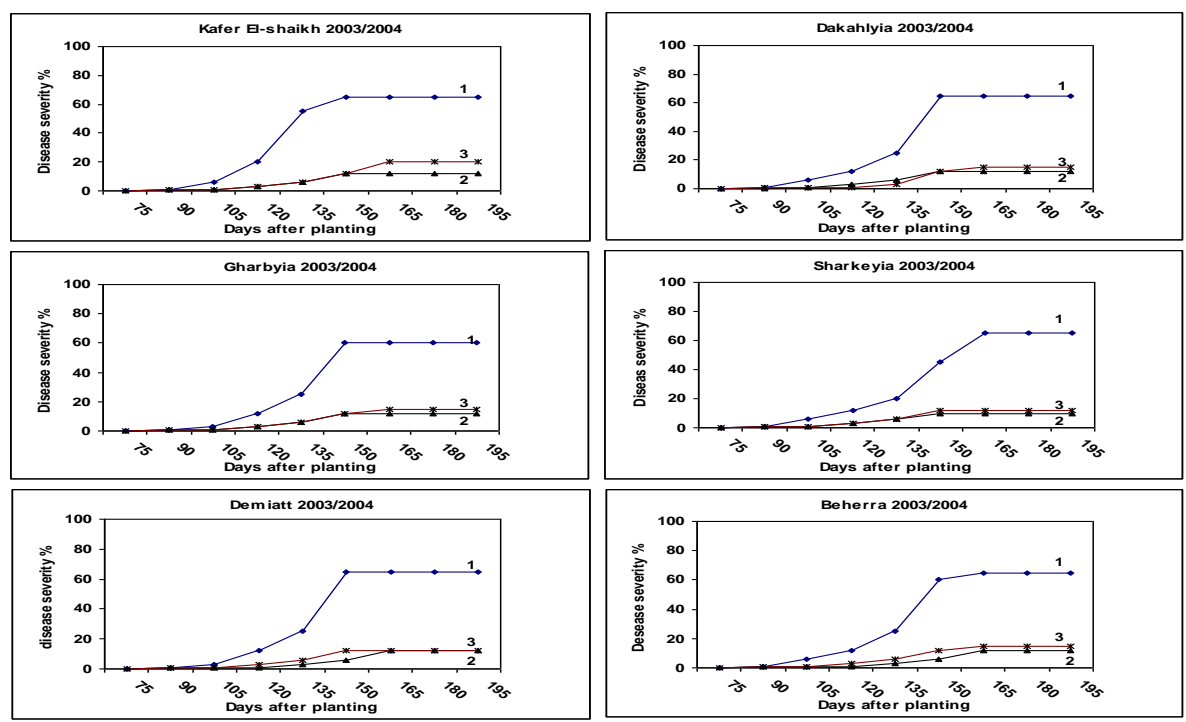

Fig (4) Disease progress curve "DPC" of Cercospora leaf spot disease of sugar beet (2003-2004). Curves No. 1, 2, 3 represents first, second \&third sowing dates respectively. 
Differences in sowing dates explained part of epidemic onset variability, as did different timings of canopy closure, presumably due to associated microclimate changes. Moreover, meteorological variables were considered as potential reasons for variation in epidemic onset (Wolf \& Verreet, 2005).

The onset and progress of CLS can be affect by previous crop, which may influence the quantity and quality of the primary inoculums (Rakhimbekova, 1977), crop rotation which may influence fungal survivability (Czajka, et al, 1996), planting dates (Akem \& Dashiell, 1994 and El-Fahhar, 1997), and sugar beet cultivars which influence disease spread, disease cycles and secondary inoculums (Wollf \& Verreet, 2005).
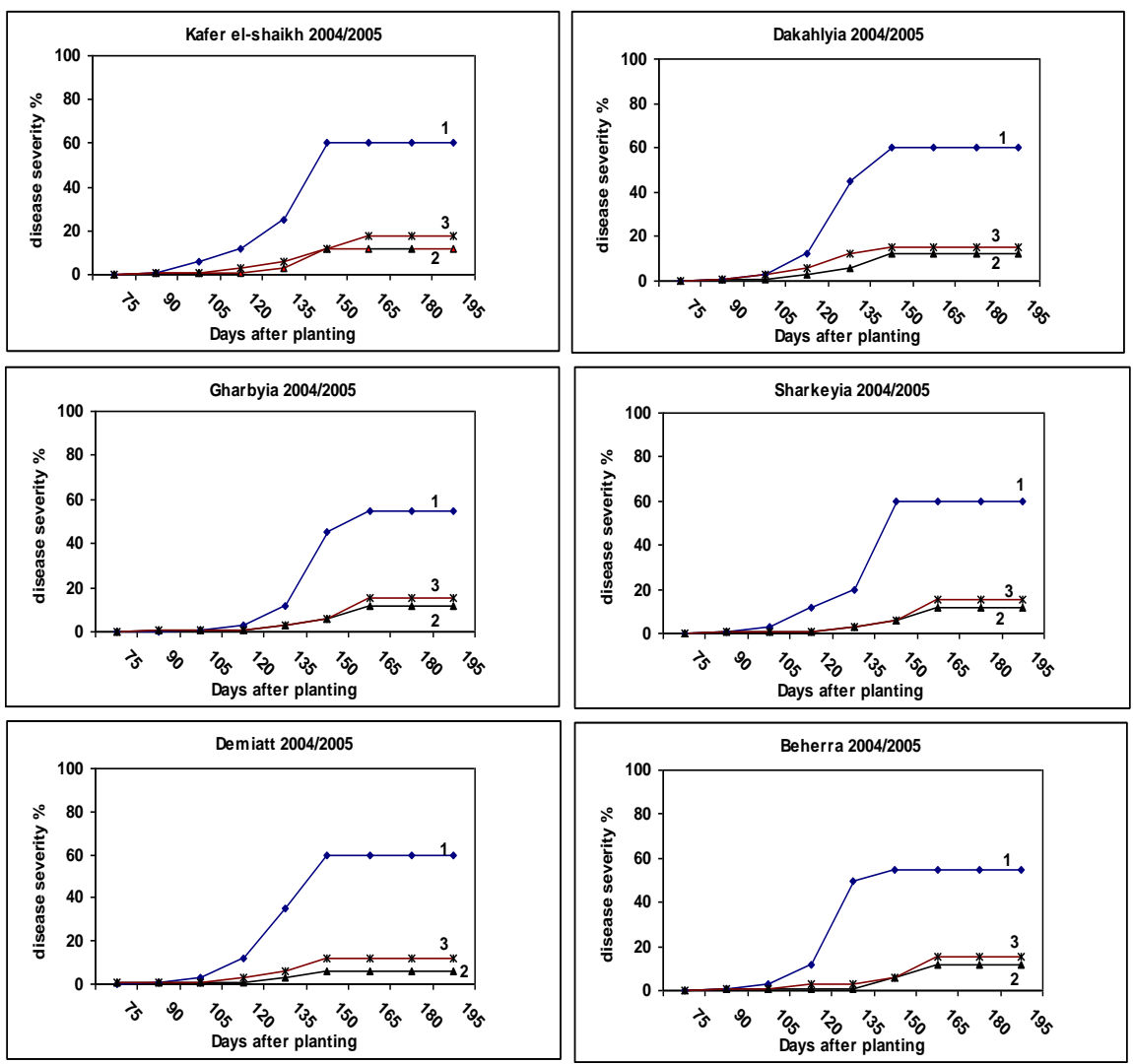

Fig (5) Disease progress curve "DPC" of Cercospora leaf spot disease of sugar beet (2004-2005). Curves No. 1, 2, 3 represents first, second \&third sowing dates respectively.

\section{Disease progress rates:}

Table, 1 summarize the estimated disease progress rates "DPR" for sugar beet fields infected by Cercospora leaf spot, through the three sowing dates, over three years (2002-2005). Presented data show that highest DPR 
Khalil,F.A.et al.

was in the $1^{\text {st }}$ (August) sowing date overall, (ranged from $0.45-0.58$ ); whereas the lowest DPR was in the $2^{\text {nd }}$ (September) (ranged from 0.04- 0.13).

Table (1): Estimation of disease progress rates "DPR" and area under disease progress curves "AUDPC" for infected sugar beet fields by Cercospora leaf spot (2002 - 2005).

\begin{tabular}{|c|c|c|c|c|}
\hline & Sowing & & Year & \\
\hline Governorate & dates & $2002 / 2003$ & $2003 / 2004$ & $2004 / 2005$ \\
\hline \multirow[t]{3}{*}{ Kafr El-Shaikh } & 1 st. & 0.58 & 0.54 & 0.50 \\
\hline & 2nd. & 0.13 & 0.10 & 0.10 \\
\hline & 3rd. & 0.17 & 0.17 & 0.15 \\
\hline \multirow[t]{3}{*}{ Dakahliya } & 1st. & 0.58 & 0.54 & 0.50 \\
\hline & 2nd. & 0.13 & 0.10 & 0.10 \\
\hline & 3rd. & 0.17 & 0.13 & 0.13 \\
\hline \multirow[t]{3}{*}{ Gharbiya } & 1st. & 0.58 & 0.50 & 0.46 \\
\hline & 2nd. & 0.13 & 0.10 & 0.10 \\
\hline & 3rd. & 0.17 & 0.13 & 0.13 \\
\hline \multirow[t]{3}{*}{ Sharkiya } & 1 st. & 0.58 & 0.54 & 0.50 \\
\hline & 2nd. & 0.08 & 0.08 & 0.10 \\
\hline & 3rd. & 0.10 & 0.10 & 0.13 \\
\hline \multirow[t]{3}{*}{ Damietta } & 1 st. & 0.58 & 0.54 & 0.50 \\
\hline & 2nd. & 0.10 & 0.10 & 0.04 \\
\hline & 3rd. & 0.13 & 0.10 & 0.09 \\
\hline \multirow[t]{3}{*}{ Behairra } & 1 st. & 0.58 & 0.54 & 0.45 \\
\hline & 2nd. & 0.13 & 0.10 & 0.10 \\
\hline & 3rd. & 0.15 & 0.13 & 0.13 \\
\hline
\end{tabular}

* $1^{\text {st }}, 2^{\text {nd }} \& 3^{\text {rd }}$ represents first (15/8-15/9), second (15/9-15/10)\&third (15/10-15/11) sowing dates respectively.

Table (2): Estimation of area under disease progress curves "AUDPC ${ }^{*}$ for infected sugar beet fields by Cercospora leaf spot (2002/ 2003).

\begin{tabular}{|l|c|c|c|c|c|c|}
\hline Governorate & Sowing & \multicolumn{7}{c|}{ Days after planting } & AUDPC & AUDPC \\
\hline & date & $\mathbf{9 0}$ & $\mathbf{1 2 5}$ & $\mathbf{1 6 0}$ & \multicolumn{2}{c|}{ (\%) $^{*}$} \\
\hline \multicolumn{7}{|c|}{} \\
\hline
\end{tabular}



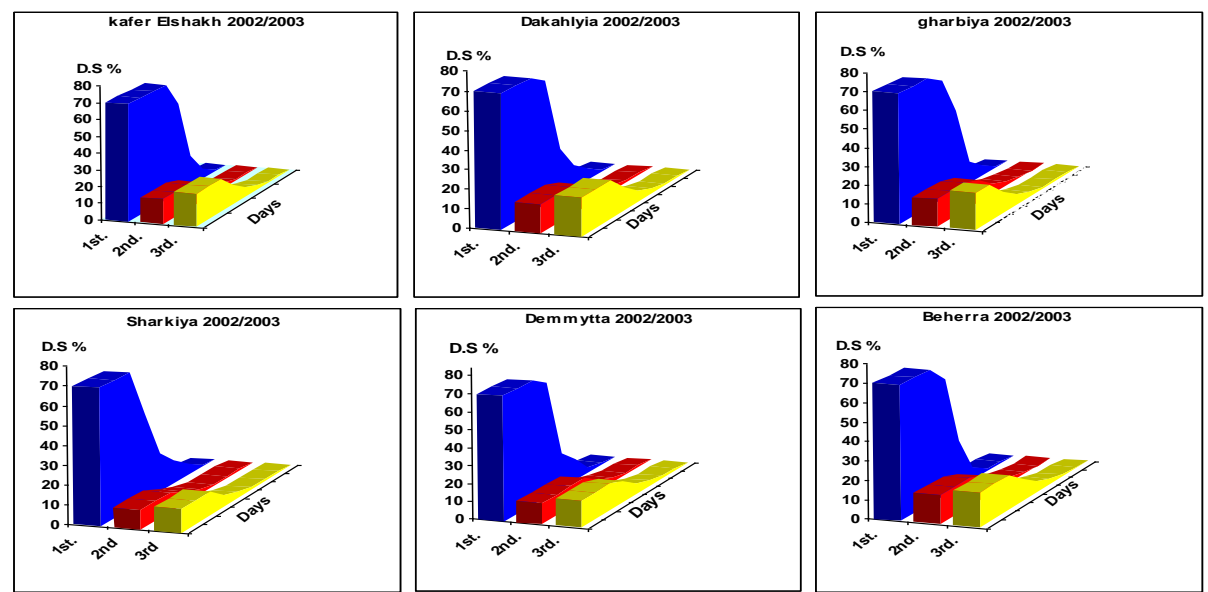

Fig (6) Area under disease progress curve "AUDPC" of Cercospora leaf spot disease of sugar beet $(2002-2003) .1^{\text {st }}, 2$ nd $\& 3^{\text {rd }}$ represents first (15/8$15 / 9)$, second $(15 / 9-15 / 10)$ \&third $(15 / 10-15 / 11)$ sowing dates respectively.

Area under disease progress curves:

Area under disease progress curve "AUDPC" can be use as descriptor for the epidemic. Table, 2, 3 \& 4 and Fig. 6, 7 \& 8 show area under disease progress curves "AUDPC" for sugar beet fields infected by Cercospora leaf spot, through the three sowing dates, over three years (2002-2005). The highest AUDPC was in the $1^{\text {st }}$ (August) sowing date overall (from 14.9-24.4\%), whereas the lowest AUDPC was in the $2^{\text {nd }}$ (September) sowing date (from $2.1-4.5 \%$ ).

Table (3): Estimation of area under disease progress curves "AUDPC" for infected sugar beet fields by Cercospora leaf spot (2003 / 2004).

\begin{tabular}{|c|c|c|c|c|c|c|}
\hline \multirow[t]{2}{*}{ Governorate } & \multirow{2}{*}{$\begin{array}{c}\text { Sowing } \\
\text { date }\end{array}$} & \multicolumn{3}{|c|}{ Days after planting } & \multirow[t]{2}{*}{ AUDPC } & \multirow{2}{*}{$\begin{array}{c}\text { AUDPC } \\
(\%)^{*}\end{array}$} \\
\hline & & 90 & 125 & 160 & & \\
\hline \multicolumn{7}{|c|}{ Disease severity \% } \\
\hline \multirow[t]{3}{*}{ Kafr ELShiekh } & 1 st. & 1 & 40 & 65 & 4642.5 & 23.2 \\
\hline & 2nd. & 0 & 1 & 15 & 795.0 & 4.0 \\
\hline & 3 rd. & 0 & 1 & 20 & 1095.0 & 5.5 \\
\hline \multirow[t]{3}{*}{ Dakahliya } & 1st. & 1 & 20 & 65 & 4072.5 & 20.4 \\
\hline & 2nd. & 0 & 6 & 15 & 780.0 & 3.9 \\
\hline & 3 rd. & 1 & 6 & 12 & 832.0 & 4.2 \\
\hline \multirow[t]{3}{*}{ Gharbiya } & 1 st. & 1 & 20 & 60 & 3765.0 & 18.8 \\
\hline & 2nd. & 0 & 3 & 18 & 795.0 & 4.0 \\
\hline & 3 rd. & 0 & 1 & 15 & 709.5 & 3.5 \\
\hline \multirow[t]{3}{*}{ Sharkiya } & $1 \mathrm{st}$. & 1 & 45 & 65 & 3697.5 & 18.5 \\
\hline & 2nd. & 0 & 1 & 10 & 690.0 & 3.5 \\
\hline & 3 rd. & 0 & 1 & 12 & 795.0 & 4.0 \\
\hline \multirow[t]{3}{*}{ Damietta } & 1st. & 0 & 30 & 70 & 4027.5 & 20.1 \\
\hline & 2nd. & 0 & 1 & 6 & 630.0 & 3.2 \\
\hline & 3 rd. & 0 & 1 & 6 & 795.0 & 4.0 \\
\hline \multirow[t]{3}{*}{ Behaira } & 1st. & 1 & 25 & 65 & 3997.5 & 20.0 \\
\hline & 2nd. & 0 & 1 & 12 & 630.0 & 3.2 \\
\hline & 3rd. & 0 & 1 & 12 & 907.5 & 4.5 \\
\hline
\end{tabular}



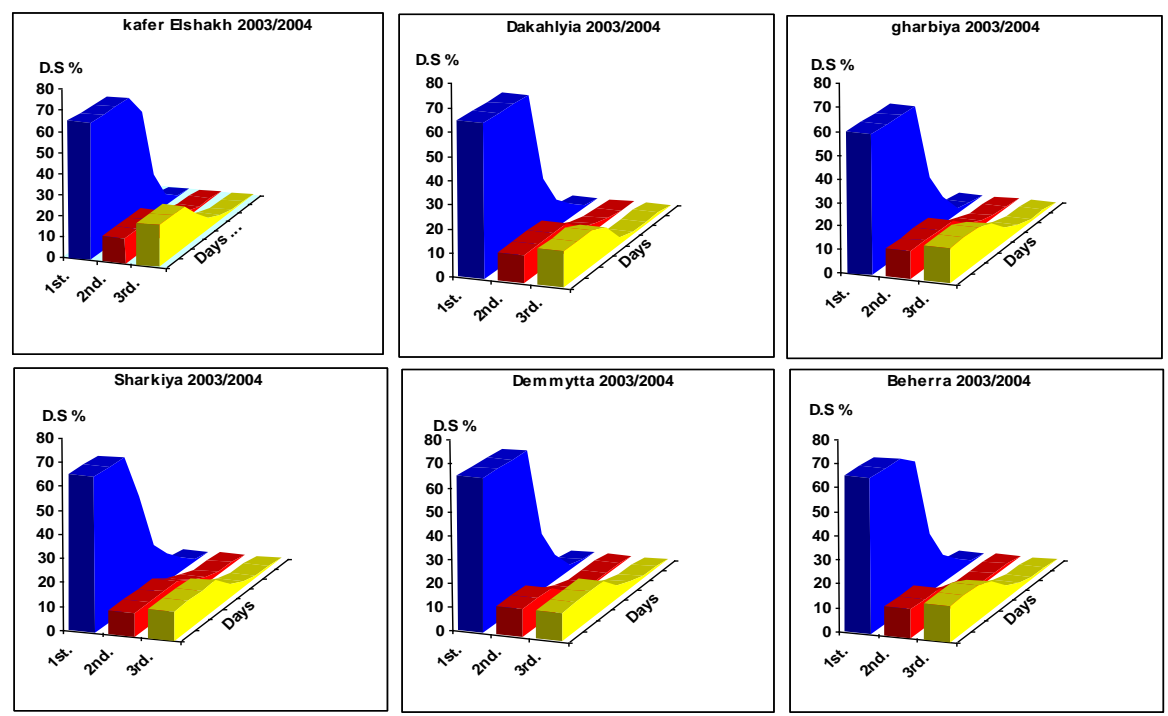

Fig (7) Area under disease progress curve "AUDPC" of Cercospora leaf spot disease of sugar beet (2003-2004). $1^{\text {st }}, 2$ nd $\& 3^{\text {rd }}$ represents first $(15 / 8-15 / 9)$, second (15/9-15/10)\&third (15/10-15/11) sowing dates respectively.

Table (4): Estimation of area under disease progress curves "AUDPC" for infected sugar beet fields by Cercospora leaf spot (2004 / 2005).

\begin{tabular}{|c|c|c|c|c|c|c|}
\hline \multirow{2}{*}{ Governorate } & \multirow{2}{*}{$\begin{array}{c}\text { Sowing } \\
\text { date }\end{array}$} & \multicolumn{3}{|c|}{ Days after planting } & \multirow{2}{*}{ AUDPC } & \multirow{2}{*}{$\frac{\text { AUDPC }}{(\%)^{\star}}$} \\
\hline & & 90 & 125 & 160 & & \\
\hline \multicolumn{7}{|c|}{ Disease severity \% } \\
\hline \multirow[t]{3}{*}{ Kafr ELShiekh } & 1 st. & 0 & 12 & 60 & 3810.0 & 19.1 \\
\hline & 2nd. & 0 & 3 & 18 & 720.0 & 3.6 \\
\hline & 3rd. & 0 & 6 & 20 & 1020.0 & 5.1 \\
\hline \multirow[t]{3}{*}{ Dakahliya } & 1 st. & 1 & 20 & 60 & 4065.0 & 20.3 \\
\hline & 2nd. & 0 & 12 & 15 & 795.0 & 4.0 \\
\hline & 3rd. & 1 & 15 & 15 & 1117.5 & 5.6 \\
\hline \multirow[t]{3}{*}{ Gharbiya } & 1 st. & 0 & 6 & 55 & 2977.5 & 14.9 \\
\hline & 2nd. & 0 & 1 & 12 & 630.0 & 3.2 \\
\hline & 3rd. & 0 & 1 & 15 & 742.5 & 3.7 \\
\hline \multirow[t]{3}{*}{ Sharkiya } & 1 st. & 0 & 20 & 60 & 3690.0 & 18.5 \\
\hline & 2nd. & 1 & 3 & 12 & 630.0 & 3.2 \\
\hline & 3rd. & 1 & 6 & 12 & 742.5 & 3.7 \\
\hline \multirow[t]{3}{*}{ Damietta } & 1 st. & 1 & 25 & 60 & 3915.0 & 19.6 \\
\hline & 2nd. & 1 & 6 & 12 & 412.5 & 2.1 \\
\hline & 3rd. & 1 & 3 & 15 & 802.5 & 4.0 \\
\hline \multirow[t]{4}{*}{ Behaira } & 1 st. & 1 & 20 & 55 & 3877.5 & 19.4 \\
\hline & 2nd. & 1 & 6 & 12 & 600.0 & 3.0 \\
\hline & 3rd. & 1 & 3 & 15 & 772.5 & 3.9 \\
\hline & & & & & & \\
\hline
\end{tabular}



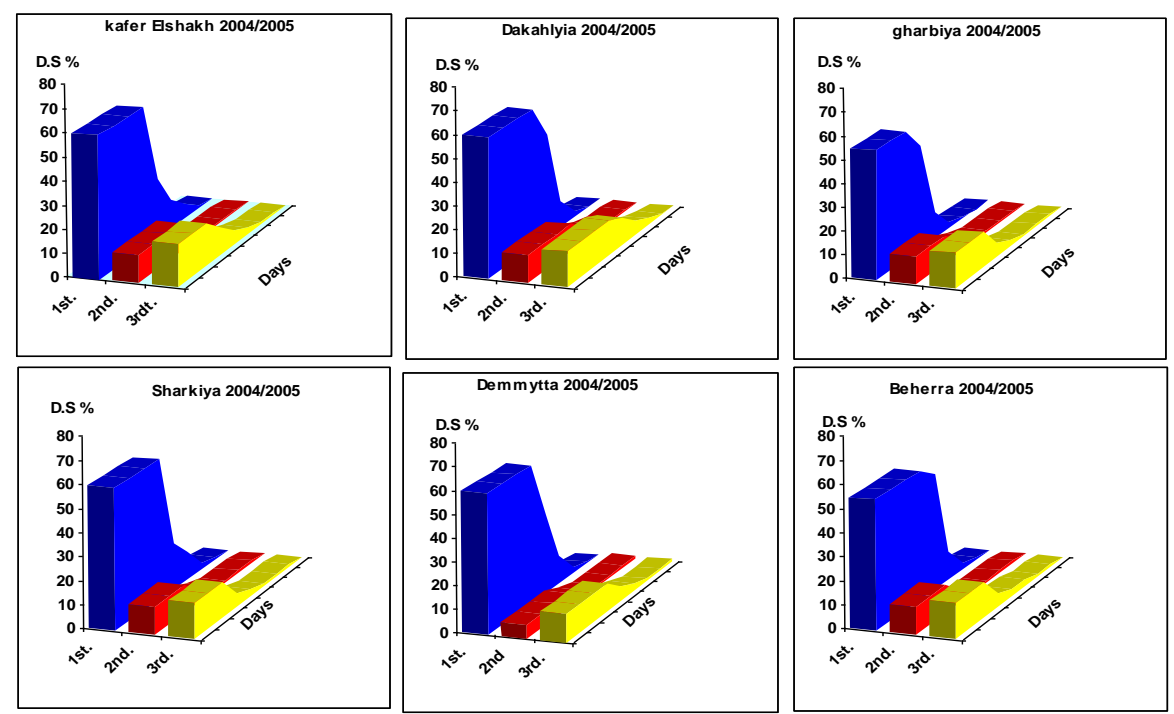

Fig (8) Area under disease progress curve "AUDPC" of Cercospora leaf spot disease of sugar beet (2004-2005). $1^{\text {st }}, 2$ nd $\& 3^{\text {rd }}$ represents first (15/8-15/9), second (15/9-15/10) \&third (15/10-15/11) sowing dates respectively.

An increase of disease progress rates "DPR" and area under disease progress curves "AUDPC" in the $1^{\text {st }}$ sowing date may be due to the presence of weather conditions favorable to the disease spread (Rossi, et, al 1995). Temperature, precipitation and moisture play a major role in many agricultural and biological processes, particularly in the occurrence and propagation of plant diseases (Laurence, et al, 2002).

Spore concentration, temperature, and duration of the wet period all influence the effects of incubation period and disease severity (wallin \& Loonan, 1972). Sporulation, germination, and infection by C. beticola are favored by day time temperatures of $25-35^{\circ} \mathrm{C}$, night temperatures above 16 ${ }^{\circ} \mathrm{C}$, and extended periods of high $\mathrm{RH}(90-95 \%)$ or free moisture on leaves (Lamey, et al, 1996). Conidia of $C$. beticola are produced most rapidly at temperatures from $20-26{ }^{\circ} \mathrm{C}$ and $\mathrm{RH}$ from 90 to $100 \%$, but don't form at temperatures less than $10{ }^{\circ} \mathrm{C}$. Ideal conditions for germination and infection occur in free water on leaves when temperature is $25-35{ }^{\circ} \mathrm{C}$ for at least 8.5 $\mathrm{h}$ (Windels, et al, 1998). These conditions are the most favorable, but infection can develop more slowly at a wider range of conditions. Disease will not develop at temperature below $10{ }^{\circ} \mathrm{C}$ and rarely when relative humidity is below $70 \%$ (Gallian, 2000). Symptoms develop from 5 to 21 days after infection, depending upon weather conditions (Windels, et al, 1998). 
Spore production and liberation, so essential to the success or failure of the development of $C$. beticola Sacc. on sugar beets. Spore formation in the field takes only a few hours during the night, and supposedly, liberation occurs in the presence of water or high relative humidity. An exponential increase in the Cercospora leaf spot disease occurred over 18 days. Disease spread was fastest downwind from the inoculated row. Long nocturnal dew periods resulted in few spores aloft at night and more spores over the sugar beets the next day (Wallin \& Loonan, 1972). Both generation and survival times of $C$. beticola spores were directly correlated with $\mathrm{RH}$.

Conidia and conidiophores of Cercospora beticola underwent violent hygroscopic movements when transferred from a saturated atmosphere to a drier one. Conidia were sometimes detached from the conidiophores as result of these movements. Although conidia were not projected more than a few microns from the conidiophores, detachment facilitate their further removal by air currents. Fewer conidia were released when the temperature was raised and relative humidity lowered, in an apparently still atmosphere. Few conidia were released and dispersed in a still, almost-saturated atmosphere maintained at constant temperature (Meredith, 1967).

Variation of predisposition influences the epidemiological behavior of C. beticola (Wolf \& Verreet 1997). Climate change as meteorological variable could alter stages, rate of development of the pathogen, modify host resistance, and result in changes in the physiology of host pathogeninteractions (Coakley, 1999).

\section{REFERENCES}

Akem, C.N. and Dashiell, K.E. (1994). Effect of planting date on severity of frogeye leaf spot and grain yield of soybeans. Crop Protection, 13(8):607-610.

Cion, F.; Tugnoli, V. and Zavanella, M. (2004). Cercospora leaf spot:The effects on sugar content reduction. Proceedings of the $67^{\text {th }}$ IIRB Congress, February 2004, Bruxelles (B).

Coakley, S.M.; Scherm, H. and Chakraborty, S. (1999). Climate change and plant disease management. Ann. Rev. Phytopathology, 37:399-426.

Czajka, W.; Cwalina, B.; Zajac, I.; Gronowicz, Z. and Czapla, J. (1996). Observation concerning the effect of crop rotation on the health state of sugar beet leaves. Acta. Academiae Agricultureae, No. 63:231-238.

El-Fahhar, Samia, A. A.(1997). Studies on some foliage disease of sugar beet in Egypt. M. Sc. Thesis, Fac., Agric., Minoufiya Univ., Egypt, $101 \mathrm{pp}$.

El-Kazzaz, M. (1977). Cercospora leaf spot disease of Chard in Egypt. Egypt. J. phytopathol., Vol. 9:80-82.

El-Kholi, M. M.(1995). Cercospora beticola Sacc. and its effect on sugar beet plants. Egypt. J. Agric. Res., 73(4):1035-1045.

El-Sayed, A. B. (2000). Integrated control of fungal leaf spots on sugar beet. M. Sc. Thesis, Fac., Agric., Minoufiya Univ., Egypt, 102pp. 
Gallian, J. J. (2000). Leaf spot of sugar beet: Identification and control. A Pacific Northwest Extension Publication-Idaho, Oregon, Washington, PNW519.

Jones, R. (1925). Mycological work in Egypt during the period 1920-1922. Min. Agric. Bull. 49.

Kranz, J. (1974). Comparison of Epidemic. Ann. Rev. Phytopathology, 12:355-374

Lamey, H. A.; Cattanach, A.W.; Bugbee, W. M. and Windels, C. E. (1996). Cercospora leaf spot of sugar beet. North Dakota state Univ. Ext. Circ. Pp-764. 4pp.

Laurence, H.; Fabry, F.; Dutilleul, P. and Bourgeois, G. (2002). Estimation of the spatial pattern of surface relative humidity using ground based rader measurements and its application to disease risk assessment. Agricultural and forest meteorology, Vol. 111(3):223-231.

Meredith, J. S. (1967). Conidium release and dispersal in Cercospora beticola. Phytopathology, 57: 889-893.

Ministry of Agriculture and Land Reclamation (2005). Area, Yield and Production of Sugar Beet Crops. Economic Affairs Sector, Agricultural Statistics, Vol, 1, Arab Republic of Egypt.

Pundhir, V. S. and Mukhopadhyay, A. N. (1987). Epidemiological studies on Cercospora leaf spot of sugar beet. Plant Pathology, 36 (2):185-191.

Rakhimbekova, A. K. (1977). The role of the predecessors in the limitation of the development of Cercosporosis of sugar beet in the southeast of Kazakhstan. S.-Kh. Inst., 19(1):83-85.

Rossi, V.; Racca, P. and Giosue, S. (1995). Geophytopathological analysis of Cercospora leaf spot on sugar beet in the Mediterranean area. Phytopathologia, Meditterranea, 34(2):69-82.

Rosso, F. (2000). Cercospora leaf disease in sugar beet. Advances in sugar beet Research, IIRB, Vol, 2:1-3.

Shane, W. W. and Teng, P. S. (1992). Impact of Cercospora leaf spot on root weight, sugar yield and purity of Beta vulgaris. Plant dis., 76:812-820.

Smith, G. A. (1985). Response of sugarbeet in Europe and the USA to Cercospora beticola infection. Agron. J. 77: 126-129.

Smith, G. A. and Martin, S. S. (1978). Differential response of sugar beet cultivation to Cercospora leaf spot disease. Crop Science, 18:39-41.

Van Der Plank, J. E. (1963). Plant disease: Epidemic and control. Academic Press. New York and London.

Wallin, J. R. and Loonan, D. V. (1972). The increase of Cercospora leaf spot in sugar beet and periodicity of spore release. Phytopathology, 62:570575.

Weiland, J. and Koch, G. (2004). Sugar beet leaf spot disease (Cercospora beticola Sacc.). Molecular Plant Pathology, 5(3):157-166.

Windels, C. E.; Lamey, H. A.; Hilde, D.; Widner, J. and Knudsen, T. (1998). A Cercospora leaf spot model for sugar beet: in practice by an industry. Plant Dis. 82: 716-726.

Wolf, P. F. J. and Vereet, J. A. (2005). Factors affecting the onset of Cercospora leaf spot epidemics in sugar beet and establishment. Disease-Monitoring Thresholds. Phytopathology, 95:269-274. 


\section{Khalil,F.A.et al.}

Wolf, P. F. J. and Verreet, J. A. (1997). Epidemiological development of Cercospora beticola (Sacc.) in sugar beet crops. J. Plant Dis. Protect. 104: 545-556.

Wolf, P. F. J. and Verreet, J. A. (2002). An integrated pest management system in Germany for the control of fungal leaf diseases in sugar beet: the IPM sugar beet model. Plant Dis. 86: 336-343.

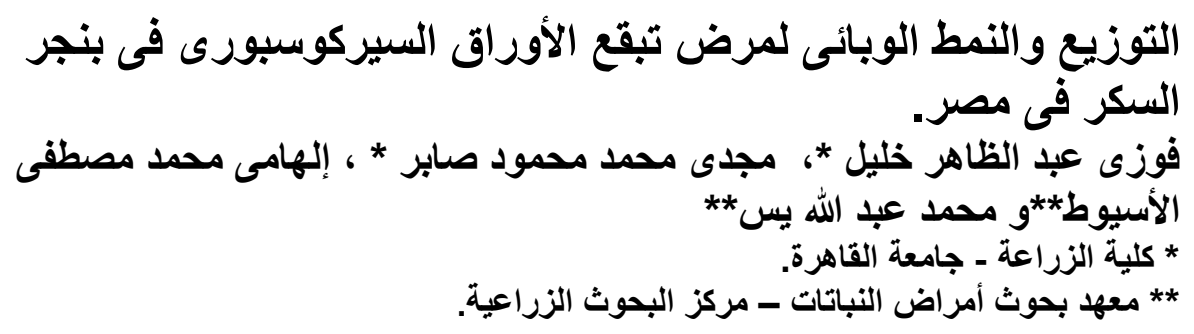

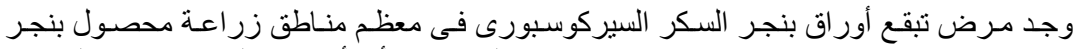

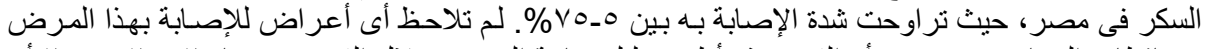

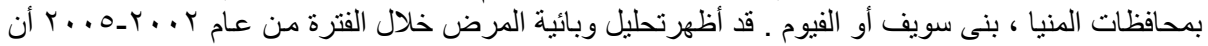

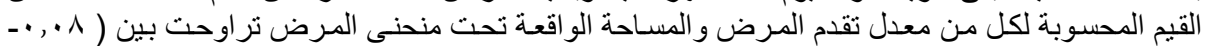

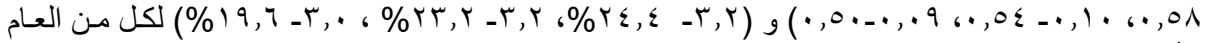

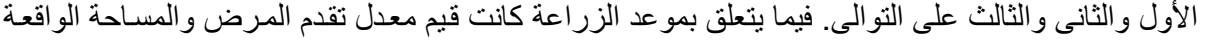

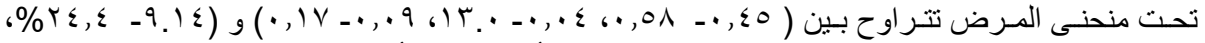

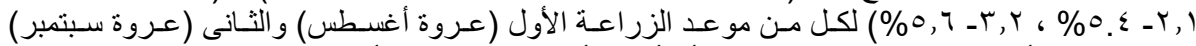

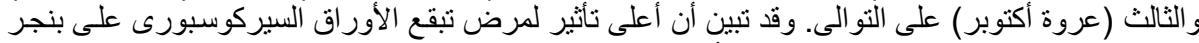

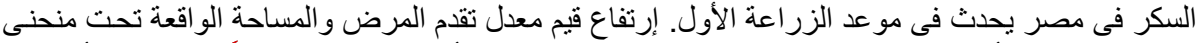

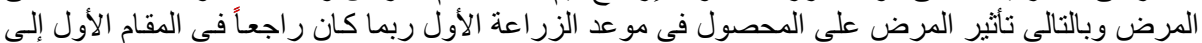
توفر الظروف البيئية المنلى للمرض فلى فلى تلك الفترة. 